\title{
ROYALTY CLAUSES IN OIL AND GAS LEASES
}

\author{
C. A. RAE*
}

\section{INTRODUCTION}

The concept of paying to the owner of a natural resource a royalty for the right, license or privilege to enter, explore for and take the resource substance is by no means a new concept. The word "royalty" originated in England where it was used to designate the share in production reserved by the Crown from those to whom the right to work mines and quarries was granted. ${ }^{1}$ From this beginning, the term was adopted by draftsmen of oil and gas leases in the United States where, in the lessor-lessee context, it is often defined as "a share of the product or profit reserved by the owner for permitting another to use the property."2 The nature of a "royalty" in Canada has often been categorized as "like rent" but this analogy, when carried beyond the lessor-lessee relationship to the carved out royalty, the production payment and the over-riding royalty where the recipient has no interest in the resource "in place", ceases to define accurately the nature of the payment or interest.

Following the adoption of the term "royalty" in the developing oil and gas industry in the United States, draftsmen devised many uses for the concept of royalty and, by the time we Canadians entered the scene, royalties in the oil and gas context were usually created in three basic ways:

1. by being reserved by the lessor in a mineral lease;

2. by being reserved by an assignor in an assignment of a mineral lease; and

3. by being granted by the lessee or an assignee of the mineral lease as a carved out interest.

Within the basic categories, however, many variations can be and have been used, as the actual terms of the royalty is a matter of contract between the parties concerned. Royalties not only vary as to amount and the substances upon which they are calculated, but may also be limited to (a) the term of the mineral lease, (b) a term of years or (c) may termminate on recovery of a fixed monetary figure. The American experience has also included a fourth method relating to the grant by a freehold mineral owner of "a $1 / 8$ royalty" when no mineral lease was then in existence. Such a grant has created numerous problems as to the nature of the interest conveyed-is it a $1 / 8$ interest in minerals in place or merely $1 / 8$ of the royalty the lessor reserves in a future mineral lease ${ }^{5}$

- Barrister and Solicitor, Calgary, Alberta. Assisted by R. B. Coleman, Barrister \& Solicitor, Calgary: M. E. Lomas, Barrister and Solicitor, Calgary and W. G. O'Rourke, Barrister \& Solicitor, Calgary, Alberta.

1 Earl A. Brown, Royalty Clauses in Oil and Gas Leases; Their Nature, Construction and Remedies for Breach Thereof, 16th Annual Institute on Oll and Gas Law and Taxation; Stroud's Judicial Dictionary, 3rd ed. vol. 3; Greville-Nugent v. Mackenzie, [1900] A.C. Stroud's Judicial Dictionary, 3rd ed. vol. 3; Greville-Nugent v. Mackenzie, [1900] A.
S3.

2 State Nat'l Bank of Corpus Christi v. Morgan,

4 When the term ends upon receiving a fixed monetary amount the interest is often referred to as a production payment which device has been extensively used in the United States in the ABC financing transaction.

5 Earl A. Brown, ante n. 1; Garrett v. Dils Co., 157 Tex. 92, 299 S.W. 2d 904, 70 \& G. R. 322 (1957); Carroll v. Fort Worth Nat' Bank, 331 S.W. $2 d$ 356, 12 o. \& G. $\mathbf{R}$. 270, (Tex. Civ. App. 1860). 
The writer has been unable to find any Canadian case on this point, but, on principle, the mineral owner should be able to create either of these interests. However, caution in drafting is warranted to determine which of the two interests will be granted by the instrument.

As this paper is being delivered in conjunction with a seminar on the petroleum and natural gas lease in use in Canada, the comments concerning royalties are limited to the royalty reserved by the mineral fee owner in granting a lease. Many of the problems concerning the lessor's reserved royalty also relate to overriding royalties and carved out royalties, and therefore observations may be of wider application.

The Canadian experience in the development of oil and gas law has been to rely, to a large extent, on the United States jurisprudence. Such reliance has been rendered necessary by the dearth of cases on oil and gas law in jurisdictions to which we customarily look for guidance in matters of commercial law. Unlike the situation presently existing in Canada, there are numerous cases in the United States concerning the many problems that have arisen with respect to royalties reserved under petroleum and natural gas leases and these, coupled with some excellent articles and text books, provides a fruitful source of material for guidance in our growing field of oil and gas law. ${ }^{\circ}$

A quick review of this wealth of source material indicates that there are varying rules and decisions depending upon the jurisdiction in which the same were decided. A rule of law applicable in Texas might not be applicable in California, Oklahoma or Louisiana and vice versa. As is always the case, decisions of foreign jurisdictions must be examined in the light of (a) that jurisdiction's prevailing concept of oil and gas ownership, (b) applicable legislative enactments and (c) local customs and constitutional law variations. As a general rule, Canadian courts have reviewed the United States decisions on oil and gas for guidance and assistance in arriving at an independent judgment which best fits the Canadian scene. ${ }^{7}$ In the absence of virtual unanimity among states, however, the weight of such source material is lessened considerably. The writer is, however, of the opinion that such cource material should be reviewed to determine its usefulness as guide posts and it is in this light that reference is made throughout to United States cases, articles and text books.

\section{Determination of "Price", "Value" or "Proceeds"}

There are numerous variations in the forms of royalty clauses ranging from a flat sum on a per well basis, to a taking in kind, and to the usual case of a percentage of the "price", "value" or "proceeds" of the substance produced. Consideration has elsewhere ${ }^{8}$ been given to the lessee's permissive deducations where the proceeds less cost method is adopted and we are here concerned primarily with the calculation of the figure from which such costs may be deducted in arriving at the "wellhead" price, value or proceeds of production for royalty purposes.

- Some of the leading American text writers, textbooks and perlodicals are: Williams, Oil and Gas Law Summers, Oil and Gas (permanent edition): Thornton, Oil and Gas (1960); Merrill, Covenants Implied in Oil and Gas Leases, (1940 2d ed.); Texas Law

7 See Canada-Cities Service Petroleum Corp. v. Kinimouth, (1964), 45. D.L.R. (2d) 36, 43-44 (Can.); Prudential Trust Co. v. National Trust Co. (1965), 47 D.L.R. (2d) 596, (Alta. C.A. McDermid J.A.).

8 Implied Obligations to Market, ante p. 318. 


\section{OII ROYalty}

In the case of royalty on oil, the lessee can usually rely on accounting to its non-operating interest owner on the basis of current posted field prices. The exception to this general rule applies in the case where the current posted field price is established to be artificial, discriminatory and substantially less than prices being paid for comparable crude in other fields. In this case the courts will, in all likelihood, apply the Oklahoma rule and hold that the royalty owner is entitled to an accounting on the basis of the "value" of the royalty oil." Such a decision would be reasonable as the value should be based on a price that would have prevailed had there existed a free and competitive market for comparable crude in the field. The operator with a monopolostic market position in the field should not be entitled to an unfair advantage over his royalty owner as a result of such position. To so hold would also be in accordance with the lessee's obligation to diligently market the production produced at reasonable prices. ${ }^{10}$ It is arguable that the royalty owner would be able to frame his action in the alternative; (a) for a breach of the implied covenant to diligently market or (b) to enforce the royalty provisions per se, in which latter case the clause excluding implied covenants would not affect the royalty owner as he is merely asking for performance pursuant to the express terms of his agreement.

\section{Gas and Products Royalty}

In the case of oil production where the usual 30 day cancellation provision in crude sale agreements applies, it is reasonably easy to determine market value, market price or proceeds of production. In contrast, however, is the case of gas production where the needs of the purchaser require a long term assurance of supply and it is difficult to determine a day to day market price in any one field. Because of this difficulty and the controversy over deductible expenses discussed elsewhere in this paper, it has been the gas royalty clause that has received the most attention in the United States and will, in the future, receive the most attention in Canada.

\section{"Market Value" - "Market Price"}

There has existed for some time a controversy in the United States to the effect that there is a distinction, in the oil and gas context, between the terms "market value" and "market price". If, in determining "market price", the courts look beyond the lessee's gas sales contract to the general contract price in the field or comparable fields, a distinction between the two terms would be most artificial.

As a general rule the market price of a commodity is what the commodity is actually sold for in the open market between sellers not forced to sell and buyers not forced to buy. ${ }^{11}$ One must use cases not relating to oil and gas with caution, however, as the meaning of the terms varies somewhat. In expropriation cases it means generally the highest price the commodity will bring for the best use to which it may be adapted.12

- Williams and Myers, Oll and Gas Law, vol. 3, 635; Continental Oil Co. v. U.S., 184 F. 2d 802 (9th Cir. 1950); Young v. West Edmond Hunton Lime Unit, 3 O. \& G. R. 1736, 40. \& G. R. 68 (Okla. 1954), 9 O. \& G. R. 534 .

10 Merrill, Covenants Implied in Oul and Gas Leases, 212-ff. (2nd ed.).

11 See, Pomilla v. Bumgarner, 326 S.W. $2 d 917$ (Tex. Civ. App. 1959); Words and Phrases, Canada, (2d ed.); J. T. Sneed, Value of Lessor's Share of Production Where Gas Only is Produced, 25 Tex. L. R. 641, 645.

12 Woods Manufacturing Co. Limited v. The King [1951] S.C.R. 504; Expropriation, Lau Soclety of Upper Canada Lectures (1958). 
In other cases it means what the item sells for on a day to day basis where each day produces a "fresh sale". In the oil and gas context these conventional meanings must be moulded to coincide with the economic reality of the sale of gas production where the price is not determined on a day to day basis and is affected by the volume of reserves, deliverability, pressure, terms of the contract and numerous other factors.

The United States experience in dealing with the royalty clause and "market price" has been to look not only at the lessee's sale agreement and its price clause but to compare and contrast all production sale contracts in the field and, in some cases, adjoining comparable fields. ${ }^{13}$ This approach is sound as the lessee should not be able to unilaterally determine the figures upon which royalty is to be calculated as would be the case if only his gas sale agreement was considered in order to determine "market price".

The royalty clause calling for a percentage of "market price" should be construed strictly by the courts and evidence going to establish "actual value", "intrinsic worth" or "reasonable price" should not be admissible except in situations where the lessor has affirmatively established that there is no market price or, if one does exist, it is artificial due to the monopolostic position of the production purchaser..$^{14}$ If, however, no such market price can be established there is authority for the argument that all factors bearing on the "value" or "worth" of the gas is admissible."

With the extensive processing being carried on today by lessees through common facilities, there often is no sale or "market price" established by sales at the wellhead, which is the point where "market price" is to be determined for royalty purposes under the usual oil and gas lease. The lack of sales at the wellhead should not open the door for the lessee to establish actual value by opinion evidence if it can be demonstrated that there is a market price at the tail gate of the processing plant. If a market price exists at the tail gate, then a fictitious market price "at the well" can be calculated by deducting the lessee's permissive deductions for transportation and processing from the tail gate price and the lessor must be content with the price as calculated.

The point remains undecided in Canada as to whether a distinction exists between the terms "current market price" and "current market value" as used in a royalty clause. While the majority of cases in the United States hold that there is no distinction between the terms, some cases such as the Texas case of Shamrock Oil and Gas Corp. v. Coffee ${ }^{16}$ do draw a distinction in holding that "market price" can only be established by actual transactions whereas "market value" can be established by opinion evidence. Inless it is established that the field wide price is artificial or depressed by a monopolistic purchaser, any sound distinction between the terms is not readily evident as the evidence of "current value" is the "current price" being paid for gas sold from the same or comparable

18 Phillips Petroleum Company v. Bynum, 155 F. $2 d 196$ (5th Cir. 1946), Certiorari denled, 67 S. Ct. 44, (1946): Sneed, ante $n$. 11 at 646; Slefkin, Rights of Lessors and Lessee With Respect to Sale of Gas and as to Gas Royalty Provisions, 4th Ann. Institute on Oil and Gas Law, 181, 186.

14 This is the majortity American view. See, G. Slefkin, ibid, at 187.

15 Katschor v. Eason Oil Co., 178 Okla. 634, 63 P. $2 d 977$ (1937); Cimarron Util. Co. v. Safranko, 187 Okla. 86, 101 P. $2 d 258$ (1940); Montreal Island Power Co. v. Town of Laval des Rapides, [1935] S.C.R. 304, 306 where Duff, C.J., stated that, "of course, It may be that there is no competitive market at the date as of which the value (price) is to be ascertained. In such circumstances, other indicla may be resorted to".

16140 F. 2d (5th Cir. 1944); Certiorari denied, 323 U.S. 737 (1944). 
fields under similar gas sale contracts. The omission of the word "current" before the terms "market value" or "price" in a royalty clause should not change the position as the royalty is paid on production when produced, saved and marketed and accordingly the word "current" should be implied in such cases.

Another area of controversy between the operating interest owner and his lessor relates to the time when the "market value" or "market price" is to be calculated. If lessee A entered into a 20 year gas sales contract in 1950 with a 1/2c escalation per year from the initial price of $10 \mathrm{c}$ per $\mathrm{McF}$ and in 1960 the price for new contracts in the field is $18 \mathrm{c}$ per $\mathrm{McF}$, is the royalty on 1960 production to be calculated on the basis of $15 \mathrm{c}$ per McF, the escalated price under the lessee's contract, or $18 \mathrm{c}$ per $\mathrm{McF}$, the price paid for gas sold under new contracts in 1960? If Canadian courts follow the recent Texas case of Foster v. Atlantic Refining Co.17 and the 18c per $\mathrm{McF}$ figure is established as the "current market value", the lessor would have an argument that it should be paid on the basis of $18 \mathrm{c}$ per $\mathrm{McF}$, if his royalty clause was comparable to that considered by the court in that case. ${ }^{18}$

It should be noted, however, that the clause in that case provided for "delivery into the pipe line" and sale "at market price-when run" and arguably was akin to an "in kind" type of clause and accoringly distinguishable from the usual type of gas royalty clause presently in use in Canada, which is not akin, in any way, to an "in kind" clause.

It is presently unknown how Canadian courts will react when presented with a fact situation comparable to the hypothetical one set out above as it presents a conflict between two principles, namely (a) the implied covenant to market with diligence at reasonable prices and (b) the literal meaning of the term, "current market value". If Canadian courts emphasize the literal meaning of "current market value" 10 in the royalty clause without regard to the other branch of the case, the unfortunate lessee will be placed in the unenviable position of being unable to comply with both obligations. ${ }^{20}$

As discussed elsewhere, ${ }^{21}$ the lessee upon discovering gas which can be commercially produced is under an implied obligation to diligently market such production at reasonable prices. If the escalated contract entered into in 1950 by the lessee was a prudent one considering the then current market price and any lessee acting in good faith would have entered into the agreement on such terms, the lessee has complied fully with his implied obligation to market. If the gas purchaser would not have given more favourable terms in 1950, should the lessee suffer a penalty

17329 F. 2d 485; 20 O. \&. G. R. 422, (5th Cir. 1964).

18 The royalty clause there considered read as follows: "the same to be delivered to the credit of the Lessor into the pipe line and to be sold at the market price therefor prevalling for the fleld where produced when run". The court did not accept the lessee's argument that as it had entered into a prudent contract in 1950 it should not be penalized for then being diligent by being obligated to pay on the basis of 18c per Mcf (the 1960 current market value) when it was getting only 15c per Mcf on its lons term sale agreement. The royalty clause was found to be clear and unambigious and the lessee knew its obligations when it entered into the 1950 agreement and any problems existing in 1960 were not webs of the courts weaving. The facts of this case were comparable to the hypothetical case set out here.

10 See, Hugoton Production Co. v. U.S., 315 F. $2 d 868,18$ O. \&. G. R. 365, (Ct. of Claims 1963), where in a tax case the court stated "that market value of gas 'at the well' is the amount that could be obtained for it under a new contract at any given time".

20 The lessee would be forced to have a "favoured nation" clause in the contract and the purchaser perhaps would not give it. If the lessee refused to sell without such a clause would he be liable for breach of his duty to market?

21 See, Problems in Development of Leased Lands, ante p. 302. 
merely because outside factors resulted in a higher price for gas in 1960 under new contracts at that time?

One cannot use the traditional concepts of market value in an industry where 20 year contracts are insisted upon by gas purchasers as each day does not produce a "fresh sale" and numerous factors enter into and affect the determination of price. It is submitted that Canadian courts should hold that "market price" in the context of the above hypothetical case means the price payable under the lessee's gas sales agreement unless the lessor can establish that the lessee failed, in entering into the agreement, to obtain the then current prices or otherwise failed to perform diligently its obligation to market the production. It is common knowledge that 20 year contracts are the rule rather than the exception and it was in this context that the term "market value" was used in the royalty clause. Also, to hold otherwise than suggested will force the lessee to hold back in selling production thereby permitting drainage and loss of immediate revenue to the lessor.

As suggested earlier, the lessee is under a duty to market with diligence and to prevent drainage. If the only way he can do this is to sell gas on a 20 year escalated price agreement, he should not be forced to suffer a penalty for compliance with this obligation just because at some later time the price of gas has increased, due, in part, to the decrease in supply by virtue of his prior deliveries. The conflict between the implied (or express) obligation to market and the literal meaning of "current market value" can be removed by holding that the term "current market value" in the gas royalty clause means "current market value" under the usual 20 year contract. In determining such value the lessee's sale agreement is referred to to see if the price stipulated in it was a provident one having regard to the current prices at the time it was entered into. If the price was a provident one, the lessee has performed his implied development obligations and should, if he accounts to his royalty owner on the basis of his provident contract prices (i.e. 15c per $\mathrm{McF}$ ), be considered to have complied fully with his royalty clause as well.

The above problem has, as yet, remained open in Canada. As a precaution lessees should refer to "actual proceeds of sale less deductions" in their royalty clauses, insist on a favoured nations clause in their gas contracts, or procure the agreement of their lessors to the effect that the lessee will be deemed to have performed its obligations under the royalty clause if it accounts on the basis of prices paid under the long term gas contract.

\section{Procegds of Sale}

While the percentage of "proceeds" or "gross proceeds" provision in the royalty clause creates problems as to permissive deductions, it is, as discussed elsewhere, ${ }^{22}$ relatively easy to determine and the lessee can account to his royalty owner on such a basis under the royalty clause. If the proceeds are too low, the lessee may be liable for breach of his covenant to diligently market but it should not be open to the lessor to successfully argue that the lessee has not complied with his royalty obligations. The terms "proceeds" or "gross proceeds" avoid the Atlantic

22 Ibid and see also E. A. Brown, Royalty Clauses in Oil and Gas Leases, 16th Annual Institute on Oil and Gas Law and Taxation; Words and Phrases, Canada, (2d ed.). "Proceeds-Gross Proceeds". 
Refining problem* for a producing lessee but it is suggested that if the courts adopt the literal meaning of the words "proceeds of sale" regardless of the point at which such proceeds are received"s, then the "market value" clause is to be preferred by a gas distribution lessee who produces and sells to ultimate consumers.

\section{Burden of Proof}

Before the lessor can succeed against the lessee in a dispute as to royalty payments it must be established that the "price", "value", "deductions" or "proceeds" are in fact different from those used by the lessee in accounting to his lessor. If the burden of proof is upon the lessor, due to the lack of information and technical data in the hands of the lessor, the weight of the burden of proof may, in many cases, prove to be decisive in favour of the lessee.

The weight of authority in the United States holds that the lessor has the burden of proof and that the lessee can therefore wait for him to establish his case without producing any evidence. ${ }^{24}$ That the Texas court in Phillips Petroleum Co. v. Bynum ${ }^{25}$ would have preferred to place the burden on the lessee is evident from their statement that: ${ }^{26}$

We have not looked with approval upon the action of the defendant in sitting back and offering no proof to aid the Court in the solution of this question, and in effect saying to its lessor: "We have taken and used, as we have seen fit, your $1 / 8$ part of the gas. Now it's up to you to prove, if you can, what we and other manufacturers pay other people, similarly situated, for their gas.' We have searched for some principle of law that would permit us to announce that when the defendant takes all the gas from the well and makes such disposition of it as best suits its purpose under a contract which does not state a definite sum to be paid for such gas, there arose either a fiduciary relation or a relation as principal and agent which would place the lessee under the duty to keep his principal fully informed and to disclose all facts that came to his knowledge and to fully and faithfully account to the lessor. But in view of the Texas law that the royalty owner has no title even to the $1 / 8$ part of the gas, and that only the contractual relation of debtor and creditor exists, we are unable to fasten the obligation to make a full disclosure where it really ought to be. We are obliged to hold that the burden is on the plaintiffs to show first that there was no market price at the well for the gas in question before they should be permitted to introduce evidence as to the actual or reasonable value thereof.

It might be argued that under our law the lessee does not by his lease acquire ownership of the petroleum or gas "in place"27 and that the lessee is really trustee of the lessor's $12.5 \%$ of production or else that the lessee sells the $12.5 \%$ as agent for the lessor. This argument may have merit in an "in kind" case but is rather weak in the usual gas situation where the lessor accounts on a percentage of "price", "value" or "proceeds" basis, rather than on a percentage of production basis.

The view taken by the Texas court is supported by the decision of the Alberta Court of Appeal in Permo Gas and Oil Limited v. Pacific Petroleums Ltd. et al. ${ }^{28}$ The Court, in a case dealing with a "favoured nations clause" held that:

He who seeks to adopt "terms" which he considers "more favourable" must satisfy the court that they are in fact just that.

- ante p.

23 A lessee who markets gas to the ultimate consumer should review the recent case of Cotiga Development Co. v. United Fuel Gas Co., W. Va., 128 S.E. 2d 626, 17 O. \& G. R. 583, (1962), before changing to the "actual proceeds" wording.

24 See, Willams and Myers, Oil and Gas Law, vol. 3 p. 649; Phillips Petroleum Co. v. Bynum, 155 F. 2d 196 (5th Cir. 1946).

25155 F. $2 d 196$.

26 Ibid at 199.

27 See, Berkheiser v. Berkheiser, [1957] S.C.R. 387.

28 (1963), 43 W.W.R. 231. 
It is submitted that the lessor in Alberta will have the same burden of proof if he desires to establish that his lessee should account to him for royalty on a basis different from that actually used by his lessee.

It should also be noted that it cannot be said with assurance that the price clause in a gas contract executed by another lessee in the field, establishes per se the then "market price" or "value". There are many factors such as volume, quality, terms of the contract, reserves and deliverability which affect the price that is to be paid for that particular lessee's gas. The inquiry insofar as a lessor plaintiff is concerned is as to his particular lessee's gas; its quality, volume and deliverability. Other long term contracts will have to be reviewed by the court with the help of expert evidence and due weight given to the varying factors mentioned above to insure that in determining the current "market price" or "value" for the field, similar factors are compared. It is not enough merely to look at the price clause. ${ }^{20}$

\section{Measurement of Production}

In a previous part of this paper reference was made to the proceeds less deductions method of calculating the royalty due to the lessor or other non-operating interest owner, whereby processing and extraction charges are deducted in arriving at the "market value" or "market price". The customary type of royalty clause does not contain provisions relating to the testing of the quality of production, the value of which is to be calculated. The absence of such reference can create problems between the lessee and the royalty owners in certain commingling situations.

If a number of companies jointly construct a gas processing plant into which gas from a number of wells in different fields or from different zones flows, can it truly be said that the products and dry gas at the tail gate can actually be allocated on the ratio of input volumes alone? If the "market price" or "market value" for the gas from a particular well is to be determined, such a determination must be based on both quality and quantity of production and a royalty owner can, it is suggested, demand his accounting on this basis in the absence of a contrary provision in the instrument establishing the royalty. ${ }^{80}$

Once it is established that the commingling lessee is oligated to conduct tests for quality, various problems and questions arise as to (a) the type of tests to be conducted, (b) the frequency of such tests and (c) the royalty owners right to inspect all such tests. The adjudicated cases on these points are rather sparce in Canada, but it can be reasonably expected that the courts will follow the majority view in the United States that, in the absence of a statute, regulation or contractual provision, controversies such as that relating to the appropriate method of sampling and of testing samples so taken will be determined on the basis of the reasonableness of the conduct of the lessee in the light of all the circumstances, with considerable attention being given to local custom if the same can be

29 See, Permo Gas and Oil Limited v. Pacific Petroleums Ltd., ibid at 236-6; Sartor v. United Gas Public Service Co., 84 F $2 d 436$ (5th Cir. 1936); Siefinin. Rights of Lessor and Lessee With Respect To Sale of Gas And As To Gas Royalty Provisions, ante n. 13 at 187.

30 See, Merrill, Covenants Implied in Oil and Gas Leases, at 222 where the writer observed: "as a part of the duty of marketing there is an obligation to measure the product accurately and to account with fldellty". 
established. ${ }^{31}$ Where there is a commingling of production from two or more fields or zones, the agreement of the working interest owners entered into from self interest and at arms length as to measurements and testing will operate to give to the lessor adequate protection. A crucial problem will arise only in the case where one lessee owns both zones or fields and there is a higher royalty on one than on the other.

Although the royalty owner will have a difficult time establishing what tests should be made and how often, the lessee of production which is commingled would still be well advised to procure, if possible, the agreement of the royalty owner on the methods by which the characteristics of the gas or oil production is to be determined for royalty purposes in a commingling situation.

One other area of contention following the recent decision of the Supreme Court of Canada in Imperial Oil Limited v. Placid Oil Comp$a n y^{32}$ has reference to the obligation of the lessee under a petroleum lease granted by the registered owner of the petroleum and calling for a 12.5\% royalty on all hydrocarbons (including natural gas) taken from the leased lands. If the same lessee held a natural gas lease from the registered owner of the natural gas and such lease called for a $12.5 \%$ royalty on natural gas, what are the lessee's aggregate gas royalty obligations if gas only is produced? Is the percentage $12.5 \%$ or $25 \%$ ?

Martland J., ${ }^{33}$ after holding that the effect of the relevant legislation was to make the Crown owner as to $1.88 \%$ of the petroleum, stated:

Applying this view of the effect of sec. 3 of the Act, it must, I think, follow that the respondent cannot be compelled to pay royalty, under provisions of the lease or the farm-out agreement, upon all the oil produced from the lands, because, of that oil, 1.88 per cent is the property of the Crown. In so far as the lease is concerned, the obligation to pay royalty is upon the leased substances owned by the lessor and leased and granted by him to the lessee. The lessee cannot be compelled to pay royalty upon oil which does not belong to the lessor, and this conclusion, which, I think, must follow, even apart from the provisions of clause 4 of the lease, is reinforced by the terms of that clause.

In view of the above statement, the lessee can frame a strong argument that as only one of the lessors "owns" the natural gas in place and he alone has the right to grant a lease thereof, the aggregate royalty obligation is only $12.5 \%$ and the registered owner of the natural gas to produced is entitled to receive such royalty. If the lessee succeeds in this argument there has been, to put it mildly, an extensive change in the law of contract in this country.

The decision of the Saskatchewan Court of Appeal ${ }^{34}$ in the same case appears to be sounder in law as they construe the statute as meaning that $1.88 \%$ of the petroleum is "deemed" to have been produced from lands other than the "said lands" as that term was used in the lease and the farmout agreement, and accordingly royalty was to be calculated on 98.12\% of the production deemed production from the lands involved. This judgment at least leaves existing contractual principles intact.

The Court in the Imperial Oil v. Placid case was dealing with a situation which was not contemplated by the parties at the time the agree-

31 See, Williams and Myers, Oil and Gas Law, 609, 612; Luling Oil and Gas Co. v. Humble Oil and Refining Co., 144 Tex. 475, 191 S.W. 2d 716, (1945); Alamitas Land Co. v. Shell Oil Co., 3 Cal, 2d 396, 44 P. $2 d$ 573, (1935).

82 (1963)." 43 W.W.'. 437. See also pages $333-350$ of within paper under heading DEDUCTIONS for text of applicable legislation and facts involved in the case.

33 Ibid at 441 .

84 (1962-63), 40 W.W.R. 412. 
ments involved were executed but rather with an event occuring later over which neither had control and which created a hardship. It might be argued that what the Court really did was imply a term in the contract in accordance with the principles of The Moorcock ${ }^{85}$ case as it could be said that, had the parties contemplated this event beforehand, each would have said "why-of course, on $98.12 \%$ and not on $100 \%$ ".

In the example previously enunciated, lessee $\mathrm{A}$ agreed with lessor B, the petroleum owner, to pay a royalty on both oil and gas taken from Blackacre. Lessee A realized that he could not get the petroleum lease unless he agreed to pay a royalty on both the oil and gas produced from the lands. The lessee entered into the agreement with eyes open and received valuable consideration thereby leaving no "hardship" to be relieved against. Since the agreement is expressed on the point, the liklihood of implying a term based on "ownership" is remote. Lessor B could have demanded from Lessee $A$ a $\$ 50,000.00$ bonus plus a $12.5 \%$ royalty on the oil produced. Why is it not possible for him to demand a $12.5 \%$ royalty on another lessor's gas, the current market value of which is $\$ 50,000.00$ ?

In the example used herein, it is submitted that the Court could easily hold that the lessor's obligation is $25 \%, 12.5 \%$ to each lessor on the gas produced from Blackacre. Because the contract is clear and unambiguous to the effect that the royalty is to be calculated on "physical" production of commodities regardless of ownership thereof it differs considerably from the Imperial Oil v. Placid situation where the agreement was "ambiguous" or a term was implied.

\section{Currency in which Royalty is Payable}

A problem may arise where production is taken from Canadian property and the royalty clause provides for payment in another country. The general rule on this point was enunciated by the Supreme Court of Canada in Weiss v. State Life Insurance Co. ${ }^{30}$ where it was stated:

It is well settled law that contracts which are to be performed by payment of money in a designated place or country require that payment shall be made in the legal tender or currency of the place set for payment. But this is only a prima facie rule or presumption, and of course is rebuttable.

The early Ontario case of Myers v. Union Natural Gas Co. ${ }^{37}$ held that where a gas royalty was payable at $131 / 2 \mathrm{c}$ per 1,000 cubic feet and the parties knew that the gas was to be sold in Canada and paid for in Canada in Canadian currency, the royalty was also payable in Canadian currency, notwithstanding that the lessors were United States citizens and the royalties were payable to their agent in the United States.

It is submitted that the general presumption is rebutted in the usual oil and gas lease situation because Canadian contract law is governing, the place of production and sale of production is in Canada, and payment for such production is made in Canada. The only foreign element is the place of payment of royalties. Even if payment is to be made in the foreign currency, is it not correct to pay the equivalent in that currency of the Canadian figure arrived at as if the contract had stipulated Canadian dollars?

85 (1889), 14 P.D. 64; Cheshire and Fifoot, Law of Contract, 139-43 (5th ed.).

36 [1935]'s.C.R. 462, 467; See also, Adelaide Blectric Supply Co. Ltd. v. Prudential Assurance Co. Ltd. [1934] A.C. 127, 151-155.

87 (1922-23), 23 O.W.N. 241. 


\section{Deductions}

\section{Legislation}

In the Provinces of Alberta, Saskatchewan and British Columbia, a large portion of the mineral rights are owned by the Crown in the Right of the Province. In addition, certain lands in these Provinces, such as Indian lands or lands administered by the Soldiers' Settlement Board or the Director under the Veterans' Land Act, are subject to the jurisdiction and control of the Crown in the Right of Canada, or of an agency thereof. In the case of these lands the lessee must not only consider the terms of his lease, but must also consider the applicable legislation. As will be seen from the statutes referred to below, legislation may be amended or repealed, thereby affecting the rights of the lessee and the royalty payable under a lease.

An attempt has been made to summarize the more important aspects of legislation of each of the said Provinces, insofar as it affects the calculation of royalties under the leases issued by the Province. Certain parts of this legislation may also affect the rights of lessors and lessees under leases of freehold mineral rights, as for example, section 7 of The Gas Utilities Act of Alberta, ${ }^{88}$ and the Road Allowance Crown Oil Act, ${ }^{39}$ 1959, of Saskatchewan.

\section{Alberta}

In Alberta over $85 \%$ of the mineral rights are owned by the Crown in the Right of the Province of Alberta. Petroleum and/or natural gas leases concerning these rights are granted pursuant to the provisions of The Mines and Minerals Act.40 Sections 31 and 141 of this Act provide that the royalty payable to the Crown shall be the royalty prescribed by the Lieutenant-Governor-in-Council. The Crown has therefore reserved the right to vary, from time to time, the royalty payable under the lease. The Crown has authority to prescribe such a variable royalty. ${ }^{41}$

Regulation $80 / 62$, passed pursuant to these sections, sets out the royalty payable on all products obtained from a petroleum and natural gas location, a petroleum location or a natural gas location. ${ }^{42}$ The regulation came into force on April 1, 1962 and shall continue in force for a period of

881960 , c. 37 .

89 1959, c. 53.

40 1962, c. 49 (Alta.)

11 See, Att. Gen. for Alberta v. Huggard Assetts Ltd., [1963] A.C. 420.

42 Regulation 80/62:

"1. The royalty to be computed, levied and collected by the Crown in right of Alberta on all products obtained from a petroleum and natural gas location, a petroleum location or a natural gas location shall be that part of the products obtained from each well during each calendar month calculated, free and clear of any deductions, as follows:

(a) with respect to crude oil, in accordance with the Schedule to these regulations;

(b) with respect to natural gas or residue gas sold or consumed for some useful purpose, sixteen and two-thirds per cent $(16-2 / 3 \%)$ of the selling price or fair value at the sixteen and two-thirds per cent (16-2/3\%) of the selling price or fair value at the time and place of production; provided that in no event shall the royalty on natural gas or residue gas be less than three-quarters of one cent (3/4c) per thousand cublc
feet (Mcf) unless the Minister otherwise directs where such gas is processed to obtain or remove sulphur, a sulphur compound, carbon dioxide or any liquid hydrocarbon; and

(c) with respect to other fluld hydrocarbons or sulphur or any product obtained by processing natural gas, sixteen and two-thirds per cent $(16-2 ; 3 \%) . "$

Schedule to Regulation $80 / 62$

"Barrel' means 34.9721 gallons

Monthly Production in Barrels Crown Royalty for the Month
in Barrels

0 to 750

750 to 2,700

2,700 and over

8 per cent of the number of barrels produced

60 plus 20 per cent of the number of barrels produced in excess of 750

$16-2 / 3 \%$ of the number of barrels produced." 
ten years thereafter until changed by the Lieutenant-Governor-in-Council. This regulation repealed Regulation 570/57, and increased the royalties which had been prescribed under that previous regulation. The royalties prescribed under the previous regulation had been in force since June 1, 1951. Where any question arises pertaining to the interpretation of Regulation $80 / 62$, the Minister is the sole judge and there is no appeal from his decision. ${ }^{43}$

Regulation 80/62 does not apply to leases of bituminous sands rights or oil sands rights. ${ }^{44}$ Regulations concerning royalties on products obtained from these rights may be passed from time to time pursuant to section 174 of The Mines and Minerals Act. Regulation 33/63 was passed under this section and sets out the royalties payable with respect to the operations of Great Canadian Oil Sands Limited, its successors and assigns, in the location described in Bituminous Sands Lease No. 4.

Sections 31 (5) of The Mines and Minerals Act states:

(5) The deductions that may be allowed when computing the royalty on petroleum and natural gas, other than crude oil, for the costs, charges and expenses incurred in gathering or processing shall be the deductions specified by the Minister.

Therefore, the Alberta Crown has reserved the right to, and in fact does, determine the deductions which may be allowed in computing royalty payable to the Alberta Crown on residue gas and plant products. Usually these deductions are determined after negotiation with the producers.

Section 32 of The Mines and Minerals Act grants the Alberta Crown a lien for royalty which is due and owing for a period in excess of sixty days. This lien attaches to all goods and chattels at or below the surface of the lands concerned and used in connection with the mining, working, recovery or production of minerals, irrespective of who may be the owner of the goods or chattels. The section states that this lien has priority over any mortgage, bill of sale, charge or any other lien arising by provincial statute or otherwise, irrespective of whether such mortgage, bill of sale, charge or lien was created before or after the lien of the Alberta Crown, or before or after the commencement of The Mines and Minerals Act and notwithstanding the provisions of any other Act. The amount of the lien may be recovered by an action for debt, or by seizing the goods and chattels which are subject to the debt. It is not proposed to discuss the merits of this legislation, or its validity in light of possible conflicting legislation. However, the section does purport to grant the Alberta Crown extremely wide powers for collecting any unpaid royalty, which collection could conceivably, under the wording of the section, be made from someone who did not owe the debt.

Section 9 of The Gas Utilities Act,"5 purports to grant to the Public Utilities Board of Alberta broad powers to determine costs and charges or deductions to be made or to be deducted by a producer for or incidental to the gathering, treating or processing of gas or any of its components. This section will be discussed later in this paper.

\section{Saskatchewan}

In Saskatchewan, over $65 \%$ of the mineral rights are owned by the Crown in the Right of the Province of Saskatchewan. The granting of

43 Paragraph 6 of the Regulation.

14 These terms are defined in section 171 of The Mines and Minerals Act.

461960, c. 37. 
petroleum and/or natural gas leases covering these rights is subject to the provisions of The Mineral Resources Act ${ }^{40}$ and the regulations passed thereunder. Section 17 of the Act provides for the payment of royalties at the times and in the manner as may from time to time be required by regulation. However, subsection (2) of section 17 provides that the Lieutenant-Governor-in-Council may approve any lease, license, permit or reservation requiring the payment of royalties specified therein in lieu of or in addition to the royalties required by the regulations.

Section 59 of the Petroleum and Nautral Gas Regulations, 1963, passed pursuant to The Mineral Resources Act, sets out the royalties payable in respect of petroleum and nautral gas rights held under a disposition from the Saskatchewan Crown granted pursuant to those regulations. The royalty prescribed on crude petroleum oil is a percentage of $98.12 \%$ of the total production from each, well, free and clear of any deduction. The royalty on natural gas in calculated on the sale value or fair value thereof, whichever is the greater, at the time and place of production. On all products other than crude petroleum oil and natural gas, including products obtained by separation, absorption or in any other manner, the royalty is calculated on the total value thereof to the producer, free and clear of any deduction whatsoever. ${ }^{47}$ The only deductions anticipated by this regulation are "any deductions which the minister may consider reasonable for costs in respect of transporting such (the Crown's) royalty share to the place of sale". As in the case of the Alberta regulations, section 58 of the Saskatchewan regulations provides that "where any question pertaining to the interpretation of this section arises the minister shall be the sole judge and there shall be no appeal from his decision."

The royalties set forth in section 58 are to continue in force for a period of ten years from April 1, 1963, and thereafter until such royalties are amended, revised or substituted by the Lieutenant-Governor-inCouncil.

46 1959, c. 84 (Sask.).

47 Section 58-Petroleum and Natural Gas Regulations-Sask.

"58. Royalty-(1) The products of all lands in respect of which the petroleum or natural gas rights are held under these regulations, or under any regulations made prior to the coming into force of these regulations, or under any regulations made by the Governor General in Council under the Dominion Lands Act shall be subject to the following royalties, or such other royalties as may from time to time be prescribed by the Lleutenant Governor in Council:

(a) On crude petroleum oil a portion of ninety-elght and twelve one-hundredths per cent of the total production from each well, free and clear of any deductions whatsoever, as determined in accordance with the following table:

Monthly Production in Barrels

0 to 600

601 to 900

901 to 1,500

1,501 to 4,950

4,951 and over Crown Royalty for the Month in Barrels

five per cent of the number of barrels of oil produced thirty barrels plus thirteen per cent of the number of barrels of oil produced in excess of six hundred

sixty-nine barrels plus seventeen per cent of the number of barrels of oil produced in excess of nine hundred

one hundred and seventy-one barrels plus eighteen per cent of the number of barrels of oll produced in excess of onethousand five hundred

sixteen per cent of the total number of barrels of oll produced;

(b) on natural Bas, eight per cent of the sale value or fair value thereof, whichever is the greater, at the time and place of production: provided that such royalty shall in no case be less than one-half of one cent per thousand cubic feet and provided further that no royalty shall be payable on natural gas consumed exclusively for drilling or production purposes on the parcels of lands in respect of which the right to the natural gas is held;

(c) on all products other than crude petroleum, oll and natural gas, including all products obtained by separation, absorption or in any other manner, eight per cent of the total value thereof to the producer, free and clear of any deduction whatsoever." 
Section 60 of the Saskatchewan Petroleum and Natural Gas Regulations provides that, notwithstanding sections 58 and 59, no Crown royalty shall be payable until December 31, 1970, on the production of petroleum and natural gas from a formation 100 feet below the top of the Devonian formation and discovered after the coming into force of this section.

The Petroleum and Natural Gas Regulations do not apply to oil shales. Royalties payable under leases of oil shales in Saskatchewan are prescribed in section 29 of The Oil Shale Regulations, 1964, passed pursuant to the Mineral Resources Act.

In 1959 Saskatchewan passed The Road Allowance Crown Oil Act, 1959. ${ }^{48}$ The intention in passing this Act was that the Saskatchewan Crown should be compensated for the minerals owned by it which are underlying road allowances. The Act therefore provides that in every producing oil reservoir:

(i) $1.88 \%$ of the recoverable oil shall be deemed to be within, upon or under road allowances and shall be the property of the Crown.

(ii) Each owner producing oil is required to pay to the minister $1 \%$ of the value, calculated on the average wellhead value, of oil produced, free and clear of any deductions, during the preceding month, or, at the election of the minister, deliver such percentage of the oil produced to the minister in kind.

(iii) After paying such $1 \%$ to the Crown the owner is free to dispose of the remaining $.88 \%$ of such $1.88 \%$ of the oil for its own behalf.

This Act was considered in Imperial Oil Ltd. v. Placid Oil Co.49 In this case Placid contended that it was entitled to deduct $1.88 \%$ of the oil produced from a well, and then calculated $12-1 / 2 \%$ royalty payable to a freehold lessor, and a 5\% overriding royalty payable to Imperial, on the remaining $98.12 \%$ of the production from the well. On the other hand Imperial argued that the law of capture applied to oil ${ }^{50}$ and that the royalties should be calculated at $100 \%$ of the production. Martland J. in delivering the judgment of the Supreme Court of Canada stated:

Lord Porter has here (in the Borys case) summarized the legal position of a landowner from within whose land oil has migrated to the land of an adjoining landowner by reasons of the operation of a well upon that land. Such, in the absence of s. 3 of the Act, would have been the legal position of the Crown in respect of oil which migrated from beneath a road allowance because of the operation of a well on adjoining lands.

Section 3, however, declares a property interest in the Crown of $1.88 \%$ of all the recoverable oil within the whole of a producing reservoir. This is a property interest, not in relation to oil situated beneath the surface of specific lands, but in respect of a portion of all the oil in the whole of a reservoir. The result is that, no matter to where the oil in that reservoir migrates, the Crown's interest remains in it and, on production, the property interest still remains.

Applying this view of the effect of s. 3 of the Act, it must I think, follow that the respondent cannot be compelled to pay royalty, under the provisions of the lease or the farm-out agreement, upon all the oil produced from the lands, because, of that oil, $\mathbf{1 . 8 8 \%}$ is the property of the Crown.

In so far as the lease is concerned, the obligation to pay royalty is upon the leased substances owned by the lessor and leased and granted by him to the lessee. The lessee cannot be compelled to pay royalty upon oil which does not belong to the lessor and this conclusion, which I think, must follow, even apart from the provisions of cl. 4 of the lease, is reinforced by the terms of that clause.

48 1959, c. 53 .

49 [1963] S.C.R. 333, 43 W.W.R. (N.S.) 437, 39 D.L.R. (2d) 244

so See Borys v. Can. Pac. Riy. Co., [1953] 2 D.L.R. 65 at 67-8, [1953] A.C. 217 at 220,7 W.W.R. (N.S.) 547 at 550 . 
There is no legislation in Saskatchewan similar to section 9 of The Gas Utilities Act of Alberta authorizing a government board to determine the costs, charges or deductions to be made or deducted by a producer. However, the Local Government Board has power under section 30 of the Public Utilities Companies Act $^{51}$ to fix a just and reasonable price or prices to be paid at the wellhead for natural gas in its natural state as and when produced from the earth. This section would not appear to grant powers of the nature contemplated by section 9 of The Gas Utilities Act of Alberta.

The Saskatchewan Crown has issued net royalty leases, whereby the lessee agrees to pay a substantial net royalty after payout in addition to, or in lieu of, paying a cash bonus at the time of the acquisition of the lease. In 1961 the Department of Mineral Resources issued a letter setting out the policy of the department with respect to the recovery under these leases of well costs and additional capital expenditures, both before and after payout. ${ }^{52}$

\section{British Columbia}

In British Columbia, so far as the writer has been able to discover, substantially all production of petroleum and natural gas discovered to date has been from lands owned by the Crown in the Right of British Columbia. The Province of British Columbia recently passed the Petroleum and Natural Gas Act. ${ }^{58}$ Part XI of this Act reserves a royalty to the British Columbia Crown on petroleum and natural gas, and sulphur obtained from processing natural gas, in such amount and payable in such manner as may from time to time be prescribed by the Lieutenant-Governor-in-Council. Section 94 of the Act provides that

(i) where the sale of natural gas takes place at a point other than the wellhead, an application may be made to the Minister for an allowance;

(ii) the Minister may approve an allowance up to but not exceeding 1-1/2c per 1,000 cubic feet of natural gas transported and,

(iii) except for an allowance authorized under the section, no deduction whatsoever shall be made from the sale price of natural gas at the point of sale for the purposes of determining the value at the wellhead.

Royalty regulations were passed under this Act on April 29, 1965. These regulations came into force on May 1, 1965, and the schedule of 
royalties set out therein is to continue in force until January 1,1975 , and thereafter until changed by the Lieutenant-Governor-in-Council. ${ }^{54}$

\section{Right of Lessee to Deduct Expenses}

The lessee will often incur expenses in treating, compressing, gathering, transporting, processing and marketing production, after obtaining such production from a well. Unless the royalty owner is taking its royalty share of production in kind at the well as and when produced, (which is not common in Alberta) a portion of these expenses will be incurred with respect to the royalty owner's share of production. The lessee must therefore consider whether it has a right to deduct from the royalty owners share of production, some, or all of these expenses incurred with respect to the royalty owner's share of production.

In considering this problem, the lessee must consider:

(i) its right under the lease to make deductions from the royalty owner's share of production,

(ii) any applicable legislation, and

(iii) what expenses are reasonable in the circumstances.

As is noted above, the Saskatchewan Crown and the British Columbia Crown will not at present permit any deductions except an allowance for transportation. In each case the amount of the transportation allowance is determined by the designated Minister. On the other hand the Alberta Crown does permit expenses to be deducted in computing its royalty share of production. However, the deductions which may be allowed, and the amount of the deductions, are in each case determined by the Minister.

The lessee of a freehold lease should carefully consider the terms of its lease in order to determine what, if any, deductions it may make from the royalty owner's share of production. Some leases provide for the

54 Royalty Regulations-B.C.

"1. The royalty reserved to the Crown in the right of the Province on all petroleum, natural gas and sulphur obtained from a location, except that lost without fault on the part of the operator as determined by the Minister, shall be that part of the production part of the operator as determined by the Minister, shall be that part

(a) with respect to crude petroleum, in accordance with the schedule to these regulations, and

(b) with respect to all other liquid hydrocarbons and sulphur obtained by processing natural gas,

(1) twelve and one-half per centum if obtained from the location of a lease issued on or before the thirty-first day of March, 1863; or

(ii) fifteen per centum if obtained from the location of a lease issued after the thirty-first day of March, 1963; and

(c) with respect to natural gas, except when used directly from the well in which it originates for production purposes or as a fuel in drilling operations on the same location, fifteen per centum, but not less than three-quarters of one cent per thousand cubic feet.

Monthly Production in Barrels

0 to 600

600 to 750

750 to 950

950 to 1,150

1,150 to 1,500

1,500 to 1,800

1,800 to 4,050

4,050 and over

\section{Schedule}

Crown Royalty for the Month in Barrels

5 per cent of the number of barrels produced.

30 plus 14 per cent of the number of barrels produced in excess of 600 .

51 plus 17 per cent of the number of barrels produced in excess of 750 .

85 plus 18 per cent of the number of barrels produced in excess of 950 .

121 plus 19 per cent of the number of barrels produced in excess of 1,150 .

12-1/2 per cent of the number of barrels produced.

225 plus 20 per cent of the number of barrels produced in excess of 1,800 .

16-2/3 per cent of the numbers of barrels produced." 
delivery of the royalty interest at the well, or provide for the royalty to be calculated on the market value at the well, or at the time and place of production. It is submitted that in these cases the lessee may deduct reasonable expenses incurred after the well, or after the place of production. However this still leaves the question of determining the place of production with respect to some products. Other forms compute the royalty share on the selling price of the production, free and clear of all costs, charges and deducations. In these cases, it would appear that the lessee does not have the right to make any deductions from the proceeds of the royalty owner's share of production.

There has been very little discussion in the Canadian courts concerning what are production costs and what are costs incurred after production. There are, however, numerous decisions concerning this problem from courts in the United States, which are discussed by Williams. ${ }^{55}$ The position in the majority of the states, as summarized by Williams, appears to be that in the absence of some express contractual provision to the contrary:

(a) Production costs, which are usually borne by the operator are costs incurred in exploring for mineral substances and bringing such substances to the surface, including

(i) costs of geophysical surveys,

(ii) drilling costs.

(iii) tangible and intangible costs incurred in testing, completing or reworking a well, including the cost of installing a christmas tree,

(iv) secondary recovery costs.

(b) Costs incurred subsequent to production which may be shared by the operator and the royalty owner include the following:

(i) gross production and severence taxes,

(ii) transportation charges or other expenses incurred in conveying the minerals produced from the wellhead to the place where the purchaser takes possession thereof,

(iii) expenses of treatment required to make the minerals saleable,

(iv) expenses of compressing gas to make it deliverable into a purchaser's pipeline (query as to the effect of recent Kansas decisions ${ }^{56}$ ),

(v) manufacturing costs incurred in extracting liquids from gas or casinghead gas, viz, costs incurred in adding value to the wellhead production,

(c) Expenses as to which there appears to be no consensus, including the following:

(i) costs of separator at or near the well, and

(ii) the expenses of measuring production for royalty purposes.

There are two important cases in Alberta concerning the deduction of costs. Both of these cases involved decisions of the Public Utilities Board of Alberta, with reference to applications under section 9 of The Gas Utilities Act (or the similar section under the former Public Utilities

55 Oil and Gas Law, vol. 3, sec. 645 .

50 Williams and Myers, Cumulative Supplement, 64, n. 8, (1964). 
Act of Alberta), and decisions of the trial and appellate divisions of the Supreme Court of Alberta, with reference to applications to interpret the provisions of the lease and appealing from decisions of the Public Utilities Board. It is proposed to discuss these cases at length.

The first of these cases involved Rabson Oil Company Limited (Rabson) and Shell Oil Company of Canada Limited (Shell). The decision of the Public Utilities Board on this application has become known as the "Jumping Pound Decision" or the "Jumping Pound Formula".

\section{Factual Background on Rabson Case}

Rabson was the lessee of both Crown and freehold leases in the Jumping Pound field and assigned these leases to Shell, which agreement (as amended) reserved unto Rabson an overriding royalty calculated as "the difference (if any) between the percentage of petroleum and natural gas (and other hydrocarbons in the case aforesaid) reserved by all other persons and/or payable by Shell to all other persons, as royalty pursuant to such petroleum and/or natural gas right and twenty per cent (20\%) of the petroleum and natural gas (and other hydrocarbons in the case aforesaid) produced, saved and removed from the lands subject to such petroleum and/or natural gas right".

The agreement further provided that:

Shell shall pay to the Assignor the over-riding royalty share of the proceeds received from the sale by Shell of natural gas produced, saved and removed from the land when produced subject to this agreement, whether such natural gas is sold in the state produced, or as residual gas after the extraction of natural gasoline or other products therefrom, and the over-riding royalty share of the market value of any natural gasoline or other products extacted from such natural gas by absorption or other process provided however (a) if Shell processes any such natural gas in any plant owned and/or operated by Shell, or causes the same to be processed in the plants of others for a consideration, it shall deduct from such payments assignor's pro rata share of the reasonable costs of processing the same; and (b) if Shell has any such natural gas processed by others involving a division of production between Shell and the processor, the over-riding royalty share payable to Assignor in respect of such production shall be calculated on the basis of the market value of the over-riding royalty share of such production received by Shell.

The leased lands subject to the assignment to Shell and others were unitized in 1945 and the above quoted provision was amended so as to refer to allocated production. Shell constructed a plant and in calculating royalties made the following deductions:

5-3/4c per MCF of residue gas for gathering and processing,

$\mathbf{7 9 . 5 \%}$ of the proceeds of sale from the natural gasoline,

$90 \%$ of the proceeds of sale from sulphur.

The Crown was the largest royalty owner in the field and this formula was negotiated with the Department of Mines and Minerals and accepted by it for a limited period of five years due to the fact that many factors were expected to change after the plant had operated for a period of time. However, the fairness of this formula was challenged by Rabson.

Shell made an application pursuant to what was then subsections (5) and (6) of section 70a of The Public Utilities Act. These subsections were later re-enacted as subsections (8) and (9) of section 72 of The Public Utilities Act, ${ }^{57}$ and eventually further re-enacted as section 9 of

S7 R.S.A. 1955, c. 267. 
The Gas Utilities Act, ${ }^{58}$ when the provisions of The Public Utilities Act were divided between The Gas Utilities Act and The Public Utilities Board Act. Apart from drafting changes, the present provisions appear to be the same as the 1952 provisions. The 1952 legislation provided as follows:

70a (5) When gas,-

(a) which is produced from any land is gathered treated or processed; or

(b) which may be produced from any land is to be gathered, treated or processed; by the producer of the gas, the Board, for the purposes of determining or establishing the value of the gas or any of its components as at the time and place of production from the well or on the location of the well, may fix and determine,-

(a) the just or fair and reasonable costs, charges or deductions; or

(b) the method, formula or basis to be applied, adopted or followed for ascertaining the just or fair and reasonable costs, charges or deductions;

to be made or to be deducted by the producer for or incidental to the gathering, treating or processing of the gas or any of its components.

(6) An order made pursuant to subsection (5),-

(a) shall apply and shall extend to such lands or areas as may be designated therein;

(b) shall apply to and shall be effective and binding upon the producer and all parties to or for whom he is or may be liable to pay or account for the gas or any portion thereof or interest therein, except and save only insofar as the same is inconsistent with any express contractual obligation of the producer which fixes or establishes specific costs, charges or deductions, or the specific method, formula or basis for escertaining the same, to be deducted or made by the producer for or incidental to the gathering, treating or processing of the gas,

(c) may be for a fixed or determinable period or periods, or may be subject to future review by the Board, as may be provided in the order and shall not be otherwise changed or varied by the Board except and only insofar as the change or variation is consented to by all of the parties affected thereby.

Shell's application was for an order determining:

(a) the just or fair and reasonable costs, charges or deductions, or

(b) the method, formula or basis to be applied, adopted or followed for ascertaining the just or fair and reasonable costs, charges and deductions

to be made or to be deducted by Shell for or incidental to the gathering, treating or processing of the gas produced from the Jumping Pound field.

It was common ground that none of the agreements contained any "express contractual obligation of the producer which fixes or establishes specific costs, charges or deductions or the specific method, formula or basis" for determining the deductions for gathering, treating or processing the gas.

Subsequent to this application and prior to any hearing, Rabson commenced a court action for:

(i) a declaratory judgment that the charges being made by Shell were not reasonable costs of processing,

(ii) alternatively, that the reasonable costs of processing referred to Shell's direct operating costs and did not enable Shell to obtain a return of capital or a profit on their processing operation, and

(iii) that an accounting be taken of Rabson's overriding royalty share of the proceeds received by Shell from natural gas or other products extracted from the said lands since January 1, 1951, and judgment be given accordingly.

881960, c. 37. 
Shell then applied to Egbert J. of the Alberta Supreme Court to strike out Rabson's statement of claim or in the alternative to stay proceedings on the ground that an application to determine the several matters here in dispute had been made by Shell to the Board of Public Utility Commissioners pursuant to the Public Utilities Act. The hearing before Egbert J. was adjourned to give the Board an opportunity to be represented.

\section{Decisions in the Rabson Case}

On November 13, 1952, Mr. G. M. Blackstock, Q.C., Chairman of the Public Utility Board, rendered a decision in which he held that the Board had jurisdiction to hear Shell's application and that the jurisdiction conferred upon it was mandatory. Accordingly, he directed a resumption of the hearing under section 70a of the Public Utilities Act. Part of his decision read as follows:

Rabson says that the Board has no jurisdiction over the contract between Shell and Rabson and to support this submission rely upon the terms of the contract already referred to under which Rabson is to receive "the overriding royalty share of the proceeds from the sale by Shell of natural gas . . . . ". In other words Rabson says that since the statute gives the Board power to determine the wellhead price of gas and may fix the just and reasonable costs and charges to be made or determined, it has no control over the end price of which Rabson is entitled to a percentage. With much respect, this is simply arguing in a circle. The determination by the Board of the matters in issue simply amounts to the determination of specific and general cost allocation. Once the principle of what constitutes costs has been determined, specific and general cost allocation is dependent upon engineering and accounting evidence, the relevance and applicability of which is the Board's function. It matters not by what proper method the wellhead price is determined for the whole issue is the balance between the end price received for the products and the proper costs to be apportioned between those products. The Board can determine the wellhead value by working back from the sale price, than which no better or more scientific way of determining wellhead values has yet been devised.

It must be remembered that in case the Board makes on Order pursuant to Subsection (5) such order shall apply to such lands or areas as may be designated therein. Any such order applies to and is effective and binding upon the producer and upon all parties with whom the producer must account. It is, however, specifically provided that in case specific costs, charges or deductions are provided for in any agreement the terms of such agreement must prevail. The Board is not given power to alter or interfere with any agreement but is merely given power to determine collectively the principles upon which costs may be determined and the quantum thereof, all of which can be summed up in the general phrase 'specific and general cost allocation.'

On January 20, 1953 Egbert J. gave a written judgment dismissing Shell's application and holding that the Public Utility Board had no jurisdiction. Egbert's J. judgment is based on five grounds which are summarized below:

(1) No jurisdiction is conferred upon the Board to hear applications of the nature of the application made to it by the defendant.

Egbert J. quoted subsections (5) and (6) of section 70a and then stated.

It will be observed that the jurisdiction purported to be conferred upon the Board by these subsections to fix and determine the just or fair and reasonable cost of the gathering, treating and processing of gas, or the method, formula or basis to be applied for ascertaining these costs, is restricted to one purpose or set of purposes-'for the purposes of determining or establishing the value of the gas or any of its components as at the time and place of production from the well, or on the location of the well'. Accordingly, it seems abundantly clear that except for the purpose of such determination or establishment of the 'value of the gas', no jurisdiction is conferred by this legislation upon the Board to fix the costs, charges or deductions, or the method, formula or basis for ascertaining them. I 
am, however, unable to find in the Act, unless it be in this section itself, any jurisdiction conferred on the Board to determine or establish 'the value' of gas at the well head.

Since no power of establishing such value is anywhere by the Act conferred upon the Board, then, in my opinion, the power to fix and determine processing costs and charges must remain dormant until such time as the antecedent jurisdiction is conferred upon the Board.

The learned Justice pointed out that, apart from statutory enactment depriving him of such right, the subject has a common law right to have his contracts interpreted by courts and has a vested interest in such rights as may exist in accordance with such interpretation. He is not to be deprived of such right and such interest unless the enactment by which it is contended he is so deprived is clearly intended to bring about that result. Statutes in derogation of the common law are to be construed strictly, and should be construed in conformity with the common law rather than against it, except where and insofar as the statute is plainly intended to alter the course of the common law.

(2) The application to the Board is not an application within the meaning of Section $70 a$ (5) of the Public Utilities Act.

With respect to this reason for his judgment the learned Justice stated:

In the case of the plaintiff in this action, the agreement provides for the payment by Shell of "the overriding royalty share of the proceeds received from the sale by Shell of natural gas products saved and recovered from the lands.' It is clear that neither the computation nor the payment of royalty has any relationship to the 'value' of the gas unless that phrase be interpreted as meaning nothing more or less than 'market selling price'. From the royalty so computed on the basis of the actual proceeds of sale, Shell is entitled to deduct the plaintiff's pro rata share of the 'reasonable costs' of processing the same. It is clear that insofar as these parties, at least, are concerned, the well-head 'value' of the gas is of no concern whatever. If the Board should 'establish or determine' such a 'value', that value would not in any way determine the computation of, or the amount of, royalty payable to the plaintiff, which would still be entitled to a percentage of the actual proceeds of sale, less a deduction for its 'pro rata' share of reasonable processing costs, and I think the same statement may fairly be made of all the other landowners in the area. The determination of well-head 'value' has nothing whatever to do with the payment or computation of royalty, or with any other practical issue arising out of the contracts between these landowners and Shell.

For these reasons I am of the opinion that the application to the Board is not an application to determine or establish the value of gas at the time and place of production, to which the fixing and determining of the treating and processing costs is incidental, but is an application purely and simply to fix and determine these costs, and as such is an application which is not within the jurisdiction of the Board to hear and determine.

(3) If subsection (5) of Section 70a of the Public Utilities Act purports to confer jurisdiction on the Board to interpret contracts it is an encroachment upon the power of the Governor-General as to the appointment of judges under Section 96 of the British North America Act.

The learned Justice stated that in his opinion the statute did not override the ordinary law of the land which would entitle Rabson to apply to the courts for an interpretation of the contract. He then stated:

However, if the statute can be interpreted as conferring any such power on the Board, then it has conferred upon the Board a jurisdiction from time immemorial exercised by Judges of Superior Courts, and such attempted bestowal of power is, in my view, a clear encroachment upon the power of the Governor-General under Section 96 of The British North America Act.

(4) If the Board is properly given jurisdiction to interpret the contract between the parties that jurisdiction is not exclusive and does not oust the jurisdiction of the courts. 
The learned Justice stated that if he were wrong in his previous conclusion then it may be that the Board and the court have concurrent jurisdiction. However, the Board's jurisdiction could not oust the jurisdiction of the courts. He then stated:

It might well be that in a proper case and to avoid the awkward situation which might arise if both jurisdictions are exercised concurrently, the Court, in cases where proceedings have first been instituted before the Board, and particularly where nothing more than a declaratory judgment is sought from the Court, should decline to exercise its jurisdiction (as was done in the case just cited), and that the Board should take similar action where proceedings have already been launched in Court.

(5) The plaintiff seeks a remedy other than a declaratory judgment, in respect of rights which accrued in the past, and with which the Board has no jurisdiction to deal.

In this part of his judgment the learned Justice pointed out that Rabson sought not only an interpretation of the agreement but an accounting and judgment for the amount found due him upon such accounting. Part of this accounting related to a period prior to the passing of subsections (5) and (6) of section 70a and the Board couldn't possibly have had jurisdiction to fix and determine the proper costs and charges with respect to that period.

A joint appeal was taken to the Appellate Division of the Supreme Court of Alberta, Rabson appealing from Mr. Blackstock's decision and Shell appealing from Egbert's J. judgment. The judgment of the Court of Appeal (which is not reported) stated:

I would dismiss the appeal of Rabson Oil Company Limited from the decision of

the Public Utility Commission, with costs to the Shell Oil Company Limited of

the appeal, for the reasons so succinctly stated in the division of the Board.

As to the right of a Province to appoint a board with the power to interpret contracts, I do not question the right of the Province to appoint a board with power to put its own interpretation on contracts in question as necessarily incidental to its proper decision. There may, of course, be an appeal from that decision according to law.

There is a claim in the action for an accounting for the period antedating the 1952 amendments. The action and appeal will be stayed pending the final decision of the Board except as to an appeal from this judgment.

No further court proceedings have been taken in this case.

The Public Utility Board then issued an order on July 29, 1954. In this decision the Board decided certain points of principle but did not determine the specific charges and deductions which could be charged by Shell. The Board held that the determination of these specific charges and deductions should be delayed until Shell's operations had become sufficiently stabilized to permit the Board to finally compute them in dollars and cents. The more important items decided by the Board in this decision are:

(1) Shell had a contractual obligation with the purchaser of the gas to treat the gas so that it could be delivered in a merchantable quality. The Board stated that Shell was able to negotiate the sale of gas and there is little doubt in the minds of the commissioners that this could only be done by Shell undertaking to convert the wet gas into a merchantable product.

(2) That the absorption plant at Jumping Pound was a necessary facility, and that Shell was obliged to construct the same. This finding was in reply to a suggestion that a method less costly than that used by Shell could be employed. 
(3) The wellhead value can be determined by working back from the sale price.

(4) That Shell is entitled to receive a return on capital invested.

(5) That income taxes are proper items to be allowed and included in the cost of the operation.

(6) General intangible costs included prior to and during construction of the plant should be allowed as part of the cost of the plant, but these costs should be supported by proof of actual costs where possible, rather than suggesting arbitrary flat percentages.

(7) Working capital, where supported by evidence based upon a study of the actual requirements in the particular operation, should be allowed as part of the cost of the plant.

(8) Depreciation, calculated on a unit basis, should be allowed as an operating charge.

On December 3, 1959 the Public Utility Board issued an order setting out the specific costs, charges and deductions which could be charged by Shell. In this decision:

(1) The Board established a rate base based on the capital invested in the plant less depreciation accumulated thereon plus working capital. The net depreciable value of the plant was to be computed at the mid point of each year.

(2) A rate of return was to be allowed at a percentage which, when multiplied by the rate base, would provide a return which fairly compensates the company for the use and risk inherent in the investments of its money. Shell did not borrow any money for the construction of the plant. However, the Board assumed the capitalization of the plant consisted of $50 \%$ debt and $50 \%$ equity capital. The Board then allowed interest charges of $5-1 / 2 \%$ on the debt and a return of $10.5 \%$ on the equity, making a composite rate of return as follows:

$50 \%$ debt at $5.5 \%$

$50 \%$ equity at $10.5 \%$ $5.25 \%$

Composite rate of return

$8 \%$

(3) The Board allowed operating expenses based upon the estimated operating and administrative expenses claimed by Shell.

(4) Depreciation based upon a unit of production system whereby the plant would be carried at its depreciated value and the annual amortization would be calculated on the basis of the remaining probable unit throughput of the plant (calculated on the estimated remaining reserves as revised from time to time).

(5) Rabson contended that Shell should not deduct income taxes unless it actually paid them. The Board however, allowed a deduction for income tax based upon the assumed net income from the plant after deducting capital cost allowance (based on the amount of depreciation booked by Shell in its financial accounts regardless of the amount it actually claimed for tax purposes) and an interest charge of $5.5 \%$ on a hypothetical debt of $50 \%$ of the plant cost. 


\section{The Pincher Creek Decision}

This case involved The British American Oil Company Limited (B.A.) and The Calgary \& Edmonton Corporation Limited (C \& E). B.A. was the lessee of $C \& E$ and other companies of leases of petroleum (which included natural gas, natural gasoline and related hydrocarbons) underlying lands in the Pincher Creek field. These lands and other lands were unitized under a unitization agreement entered into in 1956 . The royalty clause under the leases was amended, as of the date of the unitization agreement, to read as follows:

\section{Royalty}

In addition to the rental hereinbefore reserved there is and shall be payable unto the Lessor a royalty computed as hereinafter provided of all production of petroleum taken out of the leased area and such royalty shall, subject to the right of the Lessor to take its share of crude oil in kind, be paid and satisfied by payment to the Lessor of:

(a) Twelve and one-half per cent (12-1/2\%) of the current market value at the well head of all crude oil, crude naptha, casinghead gasoline produced, saved and marketed from the leased area, and

(b) Fifteen per cent $(15 \%)$ of the current market value at point of measurement of gas produced from the leased area and marketed or used off the said area or in the manufacture of casinghead gas or, if the same be treated in a plant, of the residue gas therefrom, and

(c) In the event that natural gas is transported to a plant for the purpose of extracting natural gasoline thereform or of extracting, condensing or saving additional petroleum products, by-products or sulphur,

(i) Twelve and one-half per cent (12-1/2\%) of the net amount actually received by the Lessee from the owner of such plant if the Lessee is not the owner or operator of such plant, or

(ii) Twelve and one-half per cent (12-1/2\%) of the fair current market value of such natural gas in relation to the value of the plant products derived therefrom, if the Lessee or any subsidiary is the owner or operator of such plant;

Provided that in no event shall the royalty payable to the Lessor on natural gas or residue gas be less than three-quarters of one cent $(3 / 4$ of 1c) per thousand cubic feet; and

Provided further that in the computation of the Lessor's royalty on plant products, including sulphur, the same general principles and formula employed in computing Crown royalty on similar products in the field where produced shall be applied to the computation of the Lessor's royalty thereon, varied only as to royalty percentage if and when the Crown Royalty is greater or less than the twelve and one-half per cent $(12-1 / 2 \%)$ royalty payable to the Lessor under the terms thereof.

The unitization agreement provided for the payment of royalty on allocated production, and further provided:

Provided that with respect to sulphur and fluid hydrocarbons other than crude oil, obtained by processing natural gas by compression, absorption or other plant extraction, consideration shall be given to the cost incurred in recovery or processing the sulphur or fluid hydrocarbons.

In August 1957, B.A. made application to the Public Utility Board pursuant to the Public Utilities Act "for the purpose of determining or establishing the value of gas at the time and place of production in the Pincher Creek gas field, in the Province of Alberta, and for the determination by the Board of the just or fair and reasonable costs, charges or deductions; or the method, formula or basis to be applied, adopted or followed for ascertaining the just or fair and reasonable costs, charges or deductions to be made or to be deducted by The British American Oil Company Limited for or incidental to the gathering, treating or processing of the gas produced for the Pincher Creek gas field." 
On June 25, 1959, C \& E commenced an action in the Supreme Court of Alberta against B.A., claiming that B.A. had "omitted, neglected or refused to pay to the plaintiff the full $15 \%$ royalty of the current market of residue gas," as provided in the amending agreement. The statement of claim stated that B.A. "has accounted and paid to the plaintiff royalty on the current market value of such residue gas at the point of measurement at the rate of $5 \%$ of such market value only, and the remainder of the said royalty of $15 \%$ of such current market value of such residue gas is due and owing to the plaintiff." C \& $\mathrm{E}$ requested:

(a) an accounting by the defendant to the plaintiff of all residue gas produced, sold, marketed or otherwise disposed from the unitized area apportioned and allocated to the plaintiff under the terms of the amending agreement from and after the first day of December, 1956;

(b) judgment against the defendant in an amount equal to $15 \%$ of the market value at the point of measurement of such residue gas apportioned and allocated to the land of the plaintiff included in the unitized area at the date of each sale, marketing or disposal, less such amount as shall have been found to have been paid by the defendant to the plaintiff on account thereof;

The Public Utility Board delivered its decision on December 11, 1961. In that decision the Board stated:

There is agreement between counsel for both parties that two of the issues before the Board in this application are:

(a) items which should be properly included in the rate base,

(b) the proper rate of return.

Counsel for C \& E Group suggests that the remaining issue is:

'Whether or not the Board's jurisdiction is limited to the fixing of costs and determining of formula to be applied in ascertaining such costs or in addition to determine as well the rights and obligations of the parties under private contract.'

On the other hand counsel for B.A. says:

'The real question between the parties is whether the Board has jurisdiction to give an order which will bind the members of the $C \& E$ Group to the costs, charges and deductions which will result from the method or formula approved by the Board.'

The Public Utility Board held:

The Board is satisfied that if it does have a jurisdiction in this matter that this jurisdiction is not exclusive. As indicated above $C \& E$ has commenced an action which would determine the matter which B.A. has asked the Board to decide. If the Board is right in determining that there is concurrent jurisdiction then, as pointed out by Egbert J., in the Rabson case, this might result in an awkward situation if both jurisdictions are exercised concurrently. His Lordship then goes on to suggest that in such cases either the court or the Board should decline to exercise its jurisdiction depending upon the circumstances. With the greatest respect this Board is of the opinion that if it is given jurisdiction it cannot be declined. It would appear that if such a situation develops then either one party or the other should apply to have either the proceedings before the Board or the action stayed.

While the board has no doubt that it has jurisdiction to determine the costs of the processor it does have some doubts as to whether or not it has jurisdiction to interpret the contracts of each lessor to determine if any particular lessor is responsible for the costs, charges or deductions or a particular proportion thereof. In his argument counsel for B.A. stated that if the board should doubt the sufficiency of its jurisdiction he would be prepared to argue the contention that several leases contained full provision for the deduction of costs. On the other hand counsel for the $C \& E$ Group stated that if board intended to interpret the contract then it should not do so without having evidence bearing upon the intention of the parties and other matters relevant to such interpretation.

In the circumstances the board considers that it should reserve decision on the question of jurisdiction to give counsel an opportunity to make application to have either the proceedings before this board or the action stayed. 
The Board however did go on to discuss two other issues, namely:

(1) The items which should be properly included in the rate base, and

(2) The profer rate of return.

With reference to these items the Board decided as follows:

(a) Items to be included in the rate base.

Although C \& $\mathrm{E}$ objected to certain items being included in the rate base, the Board allowed most of the contentious items on the basis that it did not feel that B.A. had acted in an unreasonable or imprudent manner in constructing its plant. However, it did disallow certain expenses in connection with preliminary well testing. In addition, and of more importance, is the fact that the Board allowed interest during construction which, because of the large investment in the plant, amounted to approximately $\$ 800,000.00$.

(b) The proper rate of return for the Pincher Creek Plant.

B.A. introduced evidence to the effect that its total corporate capitalization consisted of $15 \%$ debt and $85 \%$ equity. It requested that it be allowed a rate return of $13.5 \%$ on its $85 \%$ equity and its actual cost of debt of $5.09 \%$ on the $15 \%$ debt, resulting in an overall rate of return of $12.25 \%$. The Board confirmed its Jumping Pound decision to the effect that a reasonable capitalization for such an enterprise would be 50\% debt and $50 \%$ preferred and common equity. It therefore allowed a composite rate of return of $8.25 \%$ made up as follows:

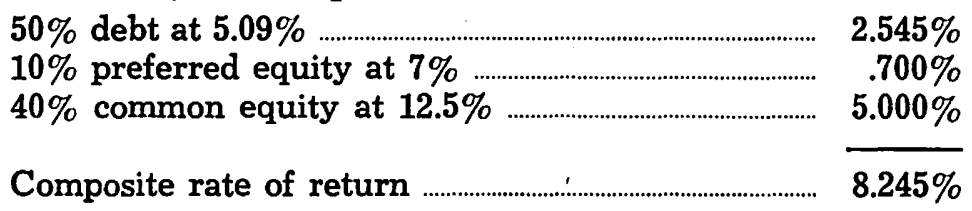

(c) The amortization and operating expenses to be allowed.

The Board allowed amortization calculated on the basis of recoverable reserves, rather than, as requested by B.A., the estimated throughput through the plant during the term of the gas sales contract with TransCanada. It further ruled that because the actual salvage value of the plant at the end of its service life would be difficult to determine at this stage, it would not at this time deduct any salvage value in determining the amount of amortization.

Because interest during construction was included in the rate base, it was not deductible as an operating expense.

Hearing expenses, amounting to approximately $\$ 61,000$, were treated as a plant operating expense for the year 1961 .

(d) The income tax deduction to be allowed.

For income tax purposes, the Board allowed a deduction of the plant's amortization rather than the capital cost allowance which had been claimed by B.A. under the Income Tax Act. As the Board pointed out, this procedure would result in B.A. charging to operations in the early years of the plant's existence an amount in excess of the tax actually paid. However, this would have an opposite effect in later years.

B.A. applied to the Supreme Court of Alberta for an order that the Supreme Court action be stayed pending delivery by the Public Utilities 
Board of a final decision on the application made to the Board by B.A. The judgment on this application was delivered by Milvain, J.50 who. after reviewing the above set of facts, held:

I have doubt of the gravest character as to whether the Province can set up a tribunal with power to interpret contracts and so settle the dispute between the contracting parties as to the proper construction to be placed upon the agreements which bind them. In my view the Rabson case does not so decide. The essential fact existing in that case was that the parties had agreed to 'a pro rata share of the reasonable costs of processing'. The Board in that case merely determined under its statutory authority what were reasonable costs of processing. The Board did not determine a dispute as to the construction to be placed on the contractual terms binding the parties.

The proper forum in which the disputed contracts must be construed is the court. The application for stay of this action is therefore refused and leave granted to proceed.

Before and after the judgment of Milvain J., B.A. applied to a Supreme Court Justice for leave to appeal the Board's decision. In each case leave to appeal was refused. B.A. then appealed to the Court of Appeal:

(a) appealing the judgment of Milvain J., and

(b) appealing from the decision of Macdonald J.A., refusing leave to appeal from the Board's decision.

The judgment of the Court of Appeal ${ }^{00}$ was delivered by Smith C.J.A.

He dismissed both appeals stating in part:

The court has not been 'denuded of jurisdiction' and I do not consider that this is a case in which the court should 'decline to exercise that jurisdiction .... and ... relegate the parties to the board ....'

The Board has plainly indicated that it will not deal with the issues between the parties unless the action is stayed or the contract is construed by the Court. This does not in my view amount to the Board refusing to function, as it was held by the Supreme Court of Canada that the Board of Railway Commissioners had in C.P.R. v. Province of Alberta, supra. To the contrary my view is that the Board, which has doubts as to its jurisdiction to decide who or what products are subject to the costs, charges and expenses which the Board determines, is acting within its jurisdiction in deciding not to proceed while the matter is being decided in the Courts.

No further proceedings in the Pincher Creek case have been taken in the Courts or before the Board. B.A. and C \& $\mathrm{E}$ have executed supplemental agreements setting out the deductions which may be made by B.A.

\section{General}

It is apparent from studying the above decisions of the Public Utilities Board and the judgments of the Courts that lessees cannot take too much comfort in section 9 of The Gas Utilities Act of Alberta. The decisions of the Public Utilities Board serve as guides as to the reasonable costs, charges and deductions for or incidental to the gathering, treating or processing of gas or any of its components which may, in the proper circumstances, be charged to the royalty owner. However, where there is a dispute with the royalty owner as to the interpretation of a royalty clause, it would appear that this dispute should be settled in the courts.

The writers are advised that the producers in at least one other gas field in Alberta have approached the Public Utilities Board for an order under section 9 of The Gas Utilities Act. The Board suggested to these producers that, as any further order would in all likelihood follow the Jumping Pound and Pincher Creek decisions, agreements should be

89 (1963) 40 D.L.R. (2d) 964

60 (1963), (44) W.W.R. 416, 40 D.L.R. (2d) 972. 
negotiated with their royalty owners along these lines. The practice now being followed in Alberta is for the producers and royalty owners to negotiate supplemental agreements, setting out the deductions, which may be charged, unless the lease sets out the specific costs, charges and deductions or a specific formula for determining them.

As mentioned earlier the deductions which may be made from royalty payable to the Alberta Crown are determined by the Minister. The Alberta Crown basically follows the Jumping Pound formula, except that certain items, such as interest on advances during construction, are not allowed.

\section{Classification of Production}

Correct classification of production from a well becomes important in the following situations:

(a) where the estates in oil and gas have been separated;

(b) where the "shut-in gas well" clause provides for the continuance of the lease where the well is capable of producing only gas;

(c) where a royalty holder is entitled to take his share of certain production (for example oil) in kind, but is compensated in money for the balance of production (for example gas);

(d) where the royalties payable on various types of production are different;

(e) where processing costs are to be deducted with respect to certain classification of production.

It is not uncommon in Alberta, particularly in early forms of petroleum and natural gas leases, to find royalty clauses specifying one rate of royalty for petroleum and another for natural gas. Quite apart from any title problem that may arise, the problems of categorizing the production from a well into one or other of these two classifications are manifest. For example:

(1) Does casinghead gas produced in association with crude oil fall within the category of petroleum or natural gas?

(2) Do the the liquid components separated from wet gas or casinghead gas fall within the category of petroleum or natural gas, or do they fall within neither of these categories?

(3) Does the sulphur removed from gas fall within the definition of natural gas or is it a product on which no royalty is payable?

Cases, such as the Borys case, ${ }^{01}$ dealing primarily with the title to petroleum and natural gas are of little assistance in construing royalty clauses. Questions as to the lessee's title to oil and gas are determined primarily by reference to the granting clause and to some extent by reference to the royalty clause. However, the question as to whether or not the lessee acquires title to the production from a well is an entirely different matter from the question as to what royalty is payable on such production. The answers to problems of classification of production depend for more upon the particular wording of the royalty clause than upon the chemical or physical properties of the product.

61 Borys v. Canadian Pacific Railway and Imperial Oil Limited, (1952-53), 7 W.W.R. (N.S.) 


\section{Casinghead Gas}

The Borys case ${ }^{62}$ is the only Canadian case dealing with casinghead gas. In that case the C.P.R. had sold certain lands to Borys reserving unto itself petroleum but not natural gas. Dealing with the question of title, the Privy Council concluded that although Borys acquired title to the gas cap, the C.P.R. had retained title to the casinghead gas produced in solution with the petroleum. The question as to what royalty, if any, was payable on the casinghead gas and the liquid constituents thereof was not in issue.

This question of what royalty, if any, is payable on casinghead gas and the liquid constituents thereof was the subject of much litigation early in the oil and gas industry's history in the United States. The leading cases have been summarized and carefully analysed by R. E. Hardwicke in, The Evolution of Casing Head Gas Law. ${ }^{63}$ However, it is impossible to reconcile the various conflicting decisions on the subject.

In Locke v. Russel ${ }^{64}$ the lease provided for a royalty of $1 / 8$ th of the oil and $\$ 200.00$ per year for each well producing gas. The lessee commenced extracting gasoline from the casinghead gas. The West Virginia Court held that such operations did not obligate the lessee to pay the royalty on gas. In Louisiana it has been held in a similar case ${ }^{65}$ that a royalty clause obligating the lessee to deliver $1 / 8$ th of the oil produced and saved from the premises did not obligate the lessee to deliver $1 / 8$ th of the gasoline and carbon black removed from casinghead gas. In Oklahoma it has been held in similar cases that casinghead gas is neither oil nor gas and consequently, since the production of casinghead gas was not within the contemplation of the parties, the lease did not authorize the removal and sale thereof. ${ }^{.6}$ The lessees were therefore obligated to account to the lessors for fair value of gasoline extracted from the casinghead gas.

In Livingston Oil Corporation v. Waggoner ${ }^{67}$ the lease provided that the lessee should deliver 1/8th of all oil produced and saved, and should pay $\$ 300.00$ per year for the gas from each well where gas only was found. The lessee sold the casinghead gas produced from the oil well. Based upon evidence that the casinghead gas was in liquid form in the reservoir the Texas Court of Civil Appeals held that the casinghead gas was a constituent part of the oil and that the lessor was therefore entitled to a $1 / 8$ th royalty thereon.

Leases which specify a royalty for casinghead gas do not necessarily resolve the problem of establishing what royalty, if any, is payable on the liquid products extracted therefrom. In Mussellem v. Magnolia Petroleum Co. ${ }^{88}$ the lease provided for a royalty of $1 / 8$ th of the oil, $\$ 300.00$ per year for gas from each well when gas only is found and $\$ 50.00$ per year on gas produced from an oil well (casinghead gas) and used off the premises. Casinghead gas was produced and sold to a company which manufactured it into gasoline on the leased premises. The Court held that the royalty on casinghead gas was applicable to such gas nothwith-

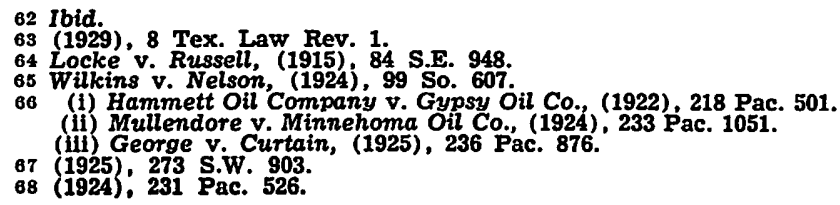


standing the fact that it was used in the manufacture of gasoline. In a similar case, ${ }^{60}$ the United States Circuit Court of Appeals held that such a royalty on casinghead gas applied only to the use of casinghead gas for fuel and therefore was not applicable where the casinghead gas was used in the manufacture of gasoline. However, the Court did hold that the $1 / 8$ th royalty on oil was applicable to the casinghead gas which had been used in the manufacture of gasoline.

In Connellee v. Magnolia Petroleum Co. ${ }^{70}$ the lease provided for a royalty of $1 / 8$ th of all oil produced and saved; $\$ 200.00$ per year for each well producing gas only; $\$ 25.00$ per year for casinghead gas from each well when sold or used off the premises; and for all other minerals $1 / 8$ th of the net profit. Magnolia manufactured gasoline on the leased premises from casinghead gas produced from oil wells. The Texas Supreme Court held that the gasoline extracted from casinghead gas was subject to the $\$ 25.00$ per year royalty on casinghead gas rather than the $1 / 8$ th royalty on oil. Apparently, the question was not argued as to whether or not the extraction of gasoline amounted to a sale or use of casinghead gas off the premises. About the same time as the Connellee case was decided, the Supreme Court of Texas considered a lease which provided a royalty of $\$ 100.00$ per year on gas produced from any oil well and used off the premises. ${ }^{71}$ In circumstances very similar to the Connellee case the Court held that this clause applied only to casinghead gas used off the premises as fuel and did not contemplate the use of casinghead gas in the manufacture of gasoline. The Court held that as the gasoline manufactured from casinghead gas was "oil", the gasoline was subjected to the $1 / 8$ th royalty on oil.

In view of the Borys case and the conflicting decisions in the United States, it is submitted that in the absence of a specific provision in the lease, Canadian courts will consider casinghead gas to be a component of oil. In all probability, the Canadian courts will conclude:

(1) That in the absence of a specific royalty on casinghead gas, this gas will be subject to the oil royalty clause in the lease.

(2) That if the lease provides a specific royalty on casinghead gas, the lessee should be obligated to pay the casinghead gas royalty on any liquid constituents extracted therefrom.

\section{Condensate}

Normally the liquid constituents contained in the gas produced from a well are separated in a separator at the wellhead, or at a gas plant located off the lease. The question then arises as to whether the royalty holder is entitled to compensation for condensate under the oil royalty clause of the lease, or does the payment of the royalty on the gas cover all constituents of the gas? The preponderance of opinion in the United States is that, in the absence of an express provision in the lease, the liquid constituents, as part of the gas, are subject to the gas royalty clause. ${ }^{72}$ 


\section{Processing Costs}

The common form of petroleum and natural gas lease now in use in Western Canada goes a long way towards solving the problem of classifying production insofar as royalty is concerned, by simply providing that there is reserved to the lessor $12.5 \%$ gross royalty on the leased substances produced and marketed from the lands. However, if there is any provision for the deduction of gas processing charges in calculating the royalty, a problem of classification may arise. Of particular interest is the decision of the United States District Court in Maddox v. Texas Co. ${ }^{73}$ where the royalty clause provided for a royalty:

(a) on oil, distillate, and condensate, one-eighth $(1 / 8$ th) of that produced and saved from the leased premises ... ;

(b) on gas (including casinghead gas and other vapors) produced from said land and sold or used off the leased premises or in the manufacture of gasoline or other products, the current market price at the wells ... of one-eighth (1/8th) of the gas so sold or used; ... (less the Lessor's share) of any compression, treating and other expenses necessary to render it merchantable.

Instead of removing condensate at the wellhead of the gas well, the lessee made a contract with a processing plant for the removal of the liquid hydrocarbons from the gas in return for a percentage of the plant products and sold the residue gas to a gas company. The lessee paid the royalty holder $1 / 8$ th of the proceeds of such contracts. The lessor claimed that under clause (a) he was entitled to 1/8th of the market price at the wellhead for the condensate and other liquids removed from the gas. The Court held that as the gas was sold or used off the premises in the manufacture of gasoline and other products, the gas royalty was payable under clause (b).

\section{Apportionment of Royalties}

Apportionment, as it applies to oil and gas leases, means the division of royalties among the owners of interests in the land that is subject to the lease. Apportionment problems arise whenever a lease covers two or more separate parcels or tracts of land and production is obtained from one of the parcels but not from the other. This situation arises:

(a) when after executing a lease the lessor conveys away a portion of the leased lands;

(b) when the lease is executed jointly by the separate owners of two or more parcels.

Under the apportionment theory, each of the owners is entitled to a proportionate share of the royalty paid on the production from the well whether or not the well is located on his property. Under the non-apportionment theory (which prevails in most of the United States of America) the royalty is payable only to the owner of the particular parcel upon which the producing well is located.

It seems that the only Canadian case dealing with the question is $R e$ Dawson \& Bell. ${ }^{74}$ In this case, the lessor granted a petroleum and natural gas lease covering 125 acres, reserving unto himself $1 / 10$ th royalty on 
oil, $\$ 100.00$ per annum for each gas well and the privilege of using enough gas to heat the dwelling located on the premises.

The lease also granted to the lessee certain rights of way and other surface rights over the lands. Two gas wells were drilled during the lessor's life-time. Upon his death, his heirs agreed that a 75 acre parcel, upon which the wells and house were situated, should be conveyed to Dawson in consideration of $\$ 6,750.00$ and the remaining 50 acre parcel should be conveyed to Bell for $\$ 2,500.00$. The question before the Ontario Court of Appeal was whether Bell was entitled to any share of the royalty payable by the lessee. The majority held:

(a) That the lease was in the nature of a profit a prendre, an incorporeal hereditament, which is an estate in lands and not a mere license.

(b) That the royalties are compensation for the right to occupy and remove oil and gas from the whole land and, being in essence rent, must necessarily be apportioned among the owners of the freehold, if the freehold is subdivided after the making of the lease.

(c) That the right to use gas for heating the dwelling was a right appurtenant to the land upon which the dwelling stood, the value of which was not to be apportioned.

In reaching its decision, the mapority relied upon three Texas cases ${ }^{75}$ and one Pennsylvania case ${ }^{76}$ as establishing that in those States the doctrine of apportionment applied. However, for some reason the majority judgment omitted to point out that in Japhet v. McRae ${ }^{77}$ the Supreme Court of Texas had reversed the first of these decisions, overruled the second and distinguished the third.

It is also interesting to note that Laidlaw, J.A., although agreeing that the royalties should be apportioned, chose to base his decision on the particular wording of the lease rather than expressing any view as to the nature of an oil and gas lease and the royalties payable thereunder. He concluded that the compensation payable was in substance rent for the use and occupation of the entire 125 acres and was therefore appurtenant to the whole acreage. In addition, he would have apportioned between the two property owners the value of the gas used for heating.

The apportionment theory is followed in the states of California, Mississippi and Pennsylvania. The principal reasons for the adoption of the rule appear to be:

(i) The royalty is deemed to be analogous to agricultural rent and should, therefore, be apportioned among the owners of the sub-divided tracts.

(ii) The royalty is not only payment for the oil and gas produced, but is also consideration for the occupation of the remaining lands.

(iii) The payment of royalty maintains the lease in existence even although there is no production from the non-producing lands. ${ }^{78}$

\footnotetext{
75 McRae v. Japhet, (1925), 269 S.W. 829; Gillette v. Mitchell, (1918), 214 S.W. 619; Hoffman v. Magnolia Petroleum Co., (1925), 273 S.W. 828 .

76 Wettengel v. Gormley, (1894), $160 \mathrm{~Pa}$. 559, $184 \mathrm{~Pa}$. 354

77 (1925). 276 S.W. 669, (Tex. Comm. App.).

78 Apportionment of Rents and Royalties among Subdivided Tracts, 1st Ann. Rocky Mountain Mineral Law Institute, 131, 139.
} 
The non-apportionment theory is followed in the states of Arkansas, Colorado, Illinois, Texas, Kansas, Kentucky, Louisana, Nebraska, New Mexico, Ohio, Oklahoma, Texas and West Virginia. ${ }^{79}$ These states apply the non-apportionment theory regardless of whether an oil and gas lease is considered to be a conveyance of real estate or the granting of a license to sever and remove oil and gas as personal property. The courts seem to take the position that since in either case, the oil and gas comprises part of the realty until it is removed or severed, the owner of the tract from which it is produced retains the rights accruing from the ownership thereof. However, even in the states applying the non-apportionment rule, there has been a tendency to apportion the royalty wherever there is the slightest evidence in the conveyance that the parties contemplated apportionment. In Hoffman v. Magnolia Petroleum Co., ${ }^{80}$ the owner of a 320 acre tract sold a half interest in the minerals under a 90 acre portion on condition that any lease granted by the purchaser must cover the full 320 acres and providing that the vendor should be entitled to "one half of all the oil royalty and gas rental or royalty due to be paid under the terms of the said lease." The Supreme Court of Texas held, in the same year as the Japhet case was decided, that the conveyance included one half of the royalty interest in the entire 320 acres.

In view of the overwhelming judicial support for the non-apportionment theory in the United States, it is not yet safe to assume that the Dawson \& Bell case will be followed by the courts of western Canada. It should be noted that McDermid, J. expressly refrained from deciding the point in Prudential Trust Company Limited v. National Trust Company Limited. ${ }^{81}$ However, it is submitted that the apportionment theory should be adopted in western Canada as being the more equitable of the two rules.

\section{The Entirety Clause}

The purpose of the "entirety clause" is to maintain the lease as a unit or entirety for drilling and development purposes, and, at the same time, pro-rate the royalty among all of the separate tracts. Most of the United States cases dealing with the "entirety clause" are concerned primarily with the question as to whether or not the wording of the conveyance is sufficient to bring the "entirety clause" into effect rather than with the construction of the "entirety clause" itself. ${ }^{82}$ This was precisely the question before the Supreme Court of Alberta in Prudential Trust Company Limited v. National Trust Company Limited. ${ }^{83}$ There, the lessor had granted a petroleum and natural gas lease covering tracts $A$ and $B$, reserving unto himself a royalty of $1 / 8$ of the oil produced and saved. The lessor assigned his royalty to Prudential Trust insofar as it covered tract A. The lessor assigned a $12.5 \%$ interest in the mines and minerals in and under tract B to National Trust together with his royalty interest insofar as it covered tract B. Subsequently, production was obtained from an oil well in tract $A$. The "entirety clause" read as follows:

If the leased premises are now or shall hereafter be owned in severalty or in separate tracts, the premises, nevertheless, shall be developed and operated as

79 Oil and Gas Law, vol. 2, para. 520.

80 (1925), 273 S.W. 828, (Tex. Comm. App.).

81 (1965), 50 W.W.R. 29.

82 For a full discussion of the United States cases see, O'Quin, "Separately Owned Tracts Under Single Lease As Affected By Entirety Clause", Eighth Annual Institute on Oil and Gas Law and Taxation, 125, (1957).

88 (1965),50 W. W. R. 29. 
one lease, and all royalties accruing hereunder shall be treated as an entirety and shall be divided among and paid to such separate owners in the proportion that the acreage owned by each such separate owner bears to the entire lease acreage.

It was held that the assignment of a $12.5 \%$ interest in the mines and minerals caused the leased premises to be owned in separate tracts, and therefore, apportionment of the royalty was required pursuant to the "entirety clause".

\section{LESSOR'S REMEdIES ON NON-PAYMENT OF ROYALTY FORFEITURE AND RE-ENTRY}

Most petroleun and natural gas leases provide that if, after written notice, the lessee does not remedy a breach of covenant, the lessor may terminate the lease and re-enter and take possession of the lands. These clauses are clearly enforceable by the lessor as owner of the reversionary estate provided that the demand for possession is made without undue delay and is unequivocable. In Publix Oil and Gas Limited v. Hinds, ${ }^{84}$ the Alberta Court of Appeal held that a lessee who grants a sub-lease of a petroleum and natural gas lease reserving unto himself a right of entry for breach of covenant, may re-enter notwithstanding the fact that the sublease operates as an assignment by virtue of the sub-lessor's failure to reserve the last day of his term. However, it has been held that where an assignment of a royalty interest is not accompanied by a transfer of the lessor's reversionary estate in the oil and gas, the assignee of the royalty is limited to the enforcement of his contractual rights. Any extinguishment of the lease, whether by surrender, merger or otherwise, will determine the assignee's right to receive royalties under the lease. ${ }^{85}$ Consequently, it is clear that unless the assignment of the royalty interest is accompanied by the transfer of the lessor's reversionary estate, the remedy of forfeiture and re-entry is not available to the assignee of the royalty interest.

\section{Distress}

The majority judgment in Publix Oil and Gas Limited v. Hinds ${ }^{86}$ observed that the net effect of a sub-lessor conveying away his leasehold estate by way of assignment rather than by way of sub-lease was that he was deprived of his right to distrain. However, in Langois v. Canadian Superior Oil of California Ltd., ${ }^{87}$ Williams, J.A., speaking for the Manitoba Court of Appeal, pointed out that in Canada since the Berkheiser case, ${ }^{88}$ a petroleum and natural gas lease is not a true lease but is a grant of a profit a prendre. Such an incorporeal hereditament does not create the relationship of landlord and tenant and the common law rights and liabilities arising out of the relation of landlord and tenant have no application to a petroleum and natural gas lease. By way of example, the court cited the landlord's common law right of distress as having no application to a petroleum and natural gas lease. However, in Alberta this conclusion must be tested against The Land Titles Act Clarification Act, ${ }^{80}$ which defines the petroleum and natural gas lease as a "lease" for certain pur-

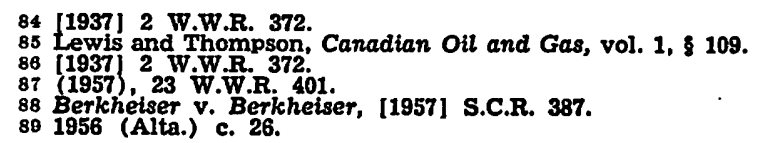


poses, and may thereby subject the parties to the relation of landlord and tenant. ${ }^{00}$

\section{Action in Contract}

The normal remedy of a lessor for non-payment of royalty is an action for breach of contract. In the case of an assignment of the lessee's interest in the petroleum and natural gas lease, the original lessee remains liable for non-payment of the royalty. The assignment of a royalty interest unaccompanied by an assignment of the reversionary estate in oil and gas constitutes an assignment of a chose in action giving rise to contractual rights only. Subject to compliance with the provisions of the Judicature Act as to the assignment being in writing, being absolute in form and notice thereof being given, the assignee may sue in his own name for the royalty payments. ${ }^{91}$

\section{ACtion IN TORT FOR CONversion}

A number of United States cases ${ }^{02}$ have held that where a lessor is entitled to a royalty in kind, he can maintain an action in tort for conversion against the lessee or the purchaser from the lessee. However, this remedy is clearly unavailable in the case of modern petroleum and natural gas leases which simply reserve unto the lessor a royalty of $12.5 \%$ of the net proceeds from the sale of the leased substances.

00 Lewis and Thompson, Canadian Oil and Gas, \& 34

91 See A. R. Thompson, Berkheiser Case and Lessor's Assignment, (1958), 1 Alta. Law Rev.

02 See cases cited in William and Myers, Oit and Gas Law, vol. 3, para 656.6. 